\title{
ĐặC ĐIỂM CỦA ĐộNG TỬ ĂN UỐNG TRONG TIẾNG HÁN VÀ TIẾNG VIẸTT
}

\author{
Ngô Minh Nguyệt* \\ Khoa Ngôn ngũu và Văn hóa Trung Quốc, Truờng Đại học Ngoại ngũ, ĐHQGHN, \\ Phạm Văn Đồng, Cầu Giấy, Hà Nội, Việt Nam \\ Nhận bài ngày 15 tháng 12 năm 2017 \\ Chỉnh sửa ngày 23 tháng 01 năm 2018; Chấp nhận đăng ngày 25 tháng 01 năm 2018
}

Tóm tắt: Ẩm thực là một trong những vấn đề trung tâm trong ngôn ngữ - văn hóa của các dân tộc, trong đó có Trung Quốc và Việt Nam. Người xưa có câu "dân dĩ thực vi thiên" (ăn là quan trọng nhất). Cùng với sự phát triển của xã hội, ăn uống dần dần vượt lên trên giá trị duy trì sự sống, vươn tới tầm nghệ thuật. Điều đó phản ánh sinh động trong ngôn ngữ. Theo đó, nhóm động từ chỉ ăn, uống trong tiếng Hán và tiếng Việt hình thành và ngày càng phong phú, khả năng kết hợp thành từ ghép và cụm từ cũng linh hoạt. Thông qua tư duy liên tưởng, tầng nghĩa ví von, so sánh của nhóm động từ này cũng trở nên đa dạng, làm giàu cho hệ thống từ vựng của hai ngôn ngữ. Trong khuôn khổ bài viết này, chúng tôi vận dụng các phương pháp và thủ pháp nghiên cứu như thống kê, miêu tả, phân tích, so sánh đối chiếu để tiến hành khảo sát và làm rõ đặc điểm ngôn ngữ - văn hóa cũng như mối tương quan giữa động từ chỉ ăn uống trong tiếng Hán và tiếng Việt.

Tù khóa: động từ ăn uống, tiếng Hán, tiếng Việt

\section{1. Đặt vấn đề}

Âm thực là một trong vấn đề cơ bản của sự tồn tại và phát triển, nó có tác động đến nhiều mặt của đời sống xã hội, trong đó có cả ngôn ngữ - văn hóa của các dân tộc như Trung Quốc và Việt Nam. Không phải ngẫu nhiên mà người xưa có câu "dân dĩ thực vi thiên" (ăn là quan trọng nhất). Từ thuở bình minh của lịch sử, trong quá trình khám phá thế giới, phục vụ đời sống, con người đã tìm ra lửa, trước hết là dùng để chế biến món ăn với những phương thức ngày càng đa dạng, làm phong phú đời sống ẩm thực cũng như đánh dấu trình độ văn minh của loài người. Cùng với sự phát triển của xã hội, văn hóa ẩm thực dần dần được hình thành, là bộ phận vô cùng quan trọng trong nền văn hóa dân tộc. Ầm thực từ tác dụng duy trì sự sống đã nâng tầm lên một môn nghệ thuật vô cùng độc đáo, nhất là ở Trung Quốc và Việt Nam, trở thành đối tượng nghiên cứu của các ngành khoa học như ngôn ngữ, văn hóa, triết học, tâm lý học, kinh tế học... Ẩm thực ngày nay còn là một trong những nhân tố có ý nghĩa quyết định đến sự tồn tại và phát triển của du lịch, được mệnh danh là "ngành công nghiệp không khói" của nền kinh tế. Trong tiếng Hán và tiếng Việt, tù̀ ngữ ẩm thực nói chung và nhóm động từ chỉ hoạt động thưởng thức món ăn, đồ uống nói riêng đều rất phong phú, đặc biệt thu hút sự quan tâm của giới nghiên cứu ngôn ngữ học và văn hóa học. Trong khuôn khổ bài viết này, chúng tôi vận dụng các phương pháp, thủ pháp nghiên cứu như thống kê, miêu tả, phân tích, so sánh đối chiếu để tiến hành khảo sát và làm rõ đặc điểm ngôn ngữ - văn hóa cũng như mối tương quan giữa các động từ về thưởng thức món ăn, đồ uống trong tiếng Hán và tiếng Việt, trong đó có nghĩa mở rộng của chúng, nhằm góp một tài liệu tham khảo cho công tác dạy học và nghiên cứu tiếng Hán ở Việt Nam.

\footnotetext{
*ĐT.: 84-982500388

Email: sanyuehua15@yahoo.com
} 


\section{2. Đôi nét về tình hình nghiên cứu từ ngữ ẩm thực}

Ẩm thực là vấn đề vô cùng quan trọng trong đời sống xã hội. Với vai trò là công cụ chuyển tải văn hóa, ngôn ngữ các nước trên thế giới nói chung và Trung Quốc, Việt Nam nói riêng đều là những tấm gương phản chiếu một cách sâu sắc, chân thực đặc điểm của từng nền ẩm thực. Vì vậy, giới nghiên cứu đặc biệt quan tâm đến từ ngữ ẩm thực và đặc trưng văn hóa của nó.

Theo tìm hiểu của chúng tôi, phần lớn các công trình nghiên cứu về từ ngữ ẩm thực đều dựa vào nội dung biểu đạt để chia thành một số tiểu loại, trên cơ sở đó tiến hành phân tích từng loại, có thể coi là những tiểu trường trong trường từ vựng ngữ nghĩa ẩm thực.

Các công trình nghiên cứu hữu quan đã công bố tại Trung Quốc phần lớn tập trung vào các động từ ẩm thực, trong đó chủ yếu là 吃 $n g a ̣ ̂ t($ ăn) - một động từ có hàm lượng văn hóa và tần suất sử dụng rất cao theo hai khía cạnh: một là, nghiên cứu nội hàm văn hóa dân tộc từ góc độ ngôn ngữ văn hóa; hai là, nghiên cứu đặc trưng trên bình diện ngữ nghĩa cú pháp.

Khi nhấn mạnh mối quan hệ giữa ngôn ngữ và văn hóa, giữa văn hóa ẩm thực và 吃

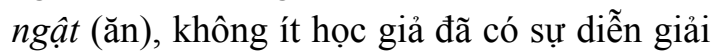
rất tường tận về quá trình diễn biến ngữ nghĩa và nguồn gốc ý nghĩa của các thành ngữ có 吃 $n g a ̣ ̂ t$ (ăn) từ góc độ lịch sử xã hội, văn hóa dân tộc và tâm lí của chủ thể. Tiêu biểu là Đổng Vi Quang (董为光, 1995) đã tập trung nghiên

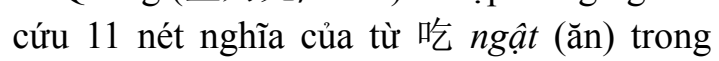
tiếng Hán từ trục dọc, và phân tích tỉ mỉ về ý nghĩa văn hóa của nó, từ đó tổng kết thành nguồn gốc văn hóa làm cơ sở tạo nên các nét nghĩa này.

Cuốn "Từ vựng tiếng Hán và văn hóa" của tác giả Thường Kính Vũ (常敬宇, 2009) đã dành riêng một phần để luận bàn về các từ ngữ có liên quan đến 吃 ngật (ăn). Từ trang 130 đến trang 150 , tác giả đã liệt kê rất nhiều từ ngữ có liên quan đến động tác ẩm thực, như 尝试 thuờng thức (nếm), 啃书本 khẳng thu bản (mọt sách), 品味 phẩm vị (thưởng thức hương vị)... Ngoài ra, trong cuốn "Ảnh hưởng của văn hóa ẩm thực Trung Hoa đối với từ ngữ tiếng Hán" xuất bản năm 1996, từ trang 139 đến trang 145, tác giả Ngụy Uy (魏威) tập trung phân tích một cách hết sức thú vị về từ vựng tiếng Hán dưới tác động của văn hóa ẩm thực qua các từ ngữ có liên quan đến động từ ẩm thực, ngoài 吃 ngật (ăn) và 喝 hát (uống) ra, còn có 狼吞虎咽 lang thôn hổ yết (ăn như rồng cuốn), 吞云吐雾 thôn vân thổ vu (vốn chỉ Đạo gia tuyệt thực để dưỡng khí, sau dùng để hình dung người nghiện ma túy hoặc thuốc lá, hít khói vào, lại thở khói ra cuồn cuộn), 字勘句酌 tư chước cú châm (cân nhắc, lựa chọn câu từ). Tác giả Lục Khánh Hòa (陆庆 和, 1995: 102-106) cũng đã thống kê và phân tích ý nghĩa rất nhiều các từ ngữ có chứa yếu tố 吃 ngật (ăn), như吃粉笔末 ngật phấn bút mạt (hình dung nghề dạy học gắn với bụi phấn và sách bút), 吃外食 ngật ngoaii thưc (từ ngữ mới của phương ngôn vùng Giang Nam, Triết Giang, chỉ nghề thứ hai của một con người)...

Từ những nghiên cứu trên đây, chúng tôi nhận thấy, những từ ngữ được cấu thành bởi 吃ngật (ăn) thường có các nghĩa mở rộng. Trong cuốn "Từ vựng tiếng Hán và văn hóa", tác giả Thường Kính Vũ đã liệt kê rất nhiều từ ngữ có sự mở rộng về ngữ nghĩa do 吃 thưc (ăn) cấu thành, bao gồm các từ ngữ dùng 食 thục (ăn) với nghĩa ví von, chẳng hạn như 䖯 食 tàm thực được ví với việc chiếm đoạt dần, và các từ ngữ trực tiếp mở rộng nghĩa của 吃 $n g a \hat{t} t$ (ăn), như 吃力 ngật lục, 吃劲 ngật kình, sử dụng với nghĩa mở rộng là "nhọc công, tốn

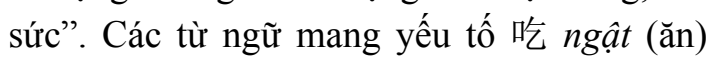
có ý nghĩa vô cùng phong phú, điều này được khẳng định trong cuốn "Nhìn thấu văn hóa trong từ ngữ tiếng Hán" của tác giả Vương Quốc An (王国安) và Vương Tiểu Mạn (王小 曼), xuất bản năm 2003. Cuốn sách có đoạn viết: "Ý nghĩa của nó có thể nói là có khả năng biến hóa khôn lường", "nó” ở đây là chỉ 
động tự吃 ngật. Đồng thời, tác giả cũng đã tổng kết các loại hình ngữ nghĩa của những từ ngữ do 吃 ngật (ăn) tạo thành, như biểu thị ý nghĩa gặp phải một điều gì đó không hay, không thuận lợi, gồm các từ 吃苦 ngật khổ (chịu khổ), 吃亏 ngật khuy (chịu thiệt), 吃官 司 ngật quan tu (bị kiện cáo)...

Lưu Đông Tuệ (刘冬慧, 2008) đã phân tích các động từ ẩm thực trong tiếng Hán cổ, trong đó, tác giả đã vận dụng các ví dụ về cấu tạo chữ, cách sử dụng lối biền ngẫu và phương ngữ để tiến hành tìm hiểu một cách toàn diện về nội hàm văn hóa ẩm thực thời cổ, qua đó nhấn mạnh mối liên hệ mật thiết giữa văn hóa ẩm thực và động từ ẩm thực.

Đối với nghiên cứu về các từ ngữ có liên quan đến mùi vị và ý nghĩa mở rộng của nó, các học giả Trung Quốc cũng đạt được nhiều thành quả đáng kể. Nhìn chung, các công trình nghiên cứu đều khẳng định, mùi vị là yếu tố vô cùng quan trọng của các món ăn Trung Quốc, vì thế mà các từ ngữ biểu thị mùi vị trong tiếng Hán cũng rất đa dạng. Việc mở rộng ý nghĩa của các từ ngữ chỉ mùi vị thông qua phương pháp liên tưởng hoặc ví von, từ đó tạo thành các từ ngữ biểu thị cảm nhận của con người. Rất nhiều nhà nghiên cứu đã chú ý đến điều này. Ví dụ, cuốn "Tiếng Hán và văn hóa truyền thống Trung Quốc" của tác giả Quách Cẩm Phù (郭锦桴, 1993:55-62) đã lần lượt phân tích phạm vi sở chỉ của những tính từ 酸 toan (chua), 甜 điềm (ngọt), 苦 $k h o ̂ ̉$ (đắng), 辣 lạp (cay) sau khi các từ này đã mở rộng nghĩa. Tác giả Triệu Thủ Huy (赵守 辉凶1991) cũng đã phân tích ý nghĩa mở rộng của các ngữ tố 酸 toan (chua), 甜 điềm (ngọt), 苦 khổ (đắng), 辣 lạp (cay), 香 huơng (thơm), 臭 $x u ́$ (thối), 味 vị (mùi/ vị) và ý nghĩa của các từ ngữ do chúng cấu thành. Ví dụ như 酸 toan (chua) có thể tạo thành các từ ngữ biểu thị tình cảm đau buồn như 心酸 tâm toan (đau lòng), 悲酸 bi toan (đau xót); hoặc có thể tạo thành các từ ngữ biểu thị cảm giác của cơ thể như 腰酸 yêu toan (đau mỏi lưng), 鼻子酸 $t i$ t tư toan (cay mũi), còn có thể dùng để hình dung một người mang sắc thái, tính cách của học trò xưa, hoặc dùng để chỉ sự nho nhã, nghèo khó,... như 穷酸 cùng toan (bần hàn/ nghèo khó), 寒酸 hàn toan (nghèo túng).

Về nghiên cứu từ ngữ có liên quan đến phương thức chế biến và ý nghĩa mở rộng của nó, các tác giả cũng khẳng định, các món ăn Trung Quốc vừa chú trọng nguyên liệu, chế biến cầu kì, lại vừa chú ý đến mức độ cao thấp của lửa, cách nấu nướng cũng vô cùng đa dạng. Những công trình nghiên cứu về mặt này phần lớn là thống kê, phân tích các từ ngữ biểu thị phương thức nấu nướng, chẳng hạn như Ngụy Uy (魏威, 1996) đã liệt kê ra các phương thức nấu nướng như 炒 sao (xào), 煎 tiến (rán), 烹 phanh (rim), 謷 ngạo (om), 者 chư (luộc). Các từ ngữ được tạo thành bởi những yếu tố này như 炒股 sao cổ (buôn bán cổ phiếu), 兔死狗烹 thố tử cẩu phanh (thỏ chết giết chó, qua cầu cất nhịp), 利欲熏 心 lợi dục huân tâm (thấy lợi tối mắt). Triệu Thủ Huy (赵守辉, 1991) cũng đã thống kê rất nhiều từ ngữ sử dụng với nghĩa mở rộng của các ngữ tố trên như 大杂烩 đại tạp khoái (sự ô hợp), 熏染 huân nhiếm (ảnh hưởng/ chịu ảnh hưởng), 謷夜 ngạo da (thức đêm).

Một số bài viết đã phân tích tường tận về nghĩa mở rộng của những từ ngữ chỉ phương thức nấu nướng, như tác giả Quách Cẩm Phù đã phân tích bản thân các ngữ tố ở trên và các từ ngữ do chúng cấu tạo thành. Thường Kính Vũ trong cuốn "Từ vựng tiếng Hán và văn hóa" cũng đã lần lượt giải thích mấy chục phương thức nấu nướng thường gặp và bàn về ý nghĩa mở rộng của các từ ngữ thường dùng có liên quan. Ví dụ, 欠火候 khiếm hỏa hầu vốn chỉ nhiệt độ không đủ khi nấu nướng, trong cuộc sống hàng ngày, từ này lại dùng để ví với xử lí công việc không đạt mức độ lí tưởng, chưa đạt tiêu chuẩn đã định, hay 煎謷 tiễn ngạo (om, sắc) vốn chỉ hai phương thức nấu nướng, đặc điểm của chúng là hành động nấu nướng phải lặp đi lặp lại, thời gian dài, vì 
vậy mà được mở rộng thành sự dày vò liên tục về tinh thần.

\section{3. Động từ chỉ ăn uống trong tiếng Hán và tiếng Việt}

Trong tiếng Việt, ẩm thưc là một từ mượn tiếng Hán, đọc theo âm Hán Việt, trong đó ẩm, ứng với chữ Hán là 饮nghĩa là uống, còn thục, ứng với chữ Hán là 食, nghĩa là ăn, thức ăn. Từ điển tiếng Hán hiện đại cũng giải thích 饮食ẩm thực là (1)thức ăn, đồ uống; (2)ăn và uống, trong đó 饮 ẩm là uống, có lúc chỉ uống rượu, còn 食 (thực) là (1)ăn ; (2)ăn cơm, thức ăn.

"Từ điển tiếng Việt" (Hoàng Phê, 2011) không tách từng thành tố $a ̂ ́ m$ và thực ra để giải nghĩa, bởi trong tiếng Việt ẩm và thực không thể độc lập thành từ. Còn từ ghép ẩm thưc thì được giải nghĩa là: ăn uống, trong đó có nhắc đến văn hóa ẩm thưc và nghệ thuật ẩm thưc.

Căn cứ vào định nghĩa từ hai cuốn từ điển nói trên, nói một cách đơn giản, ẩm thực là ăn và uống, có liên quan trực tiếp đến thức ăn và đồ uống.

Để có thể đưa ra khái niệm ẩm thực một cách cụ thể hơn, chúng tôi tìm hiểu nghĩa của hai từ ăn và uống. Theo "Từ điển tiếng Việt" (Hoàng Phê), ăn là "đưa thức ăn vào miệng và nuốt để nuôi dưỡng cơ thể", còn uống là "đưa chất lỏng vào miệng rồi nuốt".

Theo chúng tôi, lời giải thích trong từ điển

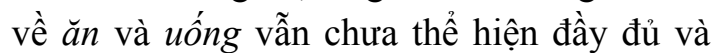
chính xác nhất nghĩa của từ ăn và từ uống, đặc biệt là từ ghép ẩm thực. Nếu chỉ đơn giản là đưa thức ăn/đồ uống vào miệng và nuốt thì việc ăn hay uống của con người quả là vô vị, và con người lúc này chẳng khác gì cái máy không có cảm xúc, lại càng không có sự tinh tế để thưởng thức, cảm nhận cái hương vị của món ngon/đồ uống ngon khi ẩm thưc đã được nâng tầm lên thành nghệ thuật. Nó chẳng khác gì việc người ta lâm bệnh nặng không thiết gì ăn uống để đến nỗi bác sỹ phải dùng ống dẫn thức ăn vào miệng. Và như vậy thì ăn uống làm sao có thể trở thành "văn hóa", thành "nghệ thuật" được?

Trước hết, phải khẳng định rằng, ăn uống gắn liền với mục đích tồn tại và hoạt động của con người, nó có liên quan mật thiết đến nguồn gốc và lịch sử của con người. Ông cha ta có câu "ăn để mà sống chứ không phải sống để mà ăn". Đó cũng có thể coi như triết lí ăn của người Việt Nam.

Ăn là hoạt động cơ bản nhất của con người, gắn liền với con người từ buổi sơ khai - thời kì nguyên thủy. Lúc này, ăn uống chỉ là một hoạt động sinh học, một phản ứng tự nhiên không điều kiện của con người, ăn theo bản năng, giống như tất cả các loài động vật khác, ăn để duy trì sự sống. Do vậy, người nguyên thủy ăn uống chưa có chọn lọc, họ ăn tất cả những gì kiếm được và đặc biệt là ăn sống, uống sống. Đó là lúc con người chưa tìm ra lửa, chưa biết sử dụng dụng cụ ẩm thực, chỉ dùng tay để bốc thức ăn (lúc đầu là thức ăn sống) đưa vào miệng nhai và nuốt (thậm chí là không nhai mà nuốt trôi luôn), miễn sao không bị đói và chết. Vì thế, mùi vị thức ăn không phải là yếu tố quan trọng bậc nhất. Có lẽ, định nghĩa trong các từ điển xuất phát từ bản năng sinh học của con người để đưa ra lời giải thích về ăn.

Về sau, qua trải nghiệm, để khắc phục những khó khăn khi dùng tay bốc thức ăn, con người đã sử dụng các đồ vật trong tự nhiên để làm dụng cụ ẩm thực, từ việc dùng xiên, đến dùng thìa, dĩa, đũa... là cả một bước tiến quan trọng trong lịch sử ẩm thực của loài người.

Từ khi con người tìm ra lửa, các dụng cụ ẩm thực dần dần được chế tạo chau chuốt hơn, đời sống cũng ngày càng phát triển, văn minh hơn, thì ăn lúc này đã không đơn thuần là đưa thức ăn vào miệng, nhai và nuốt nữa. Trước hết là khâu chuẩn bị thức ăn với nguồn nguyên liệu và đặc biệt là chế biến thức ăn, ban đầu là làm chín thức ăn, bày biện thức ăn ra bát, đĩa, rồi sau đó mới thực hiện động tác đưa thức ăn vào miệng, nhai và nuốt, con người bắt đầu có cảm nhận về thức ăn chế biến. F.Enghen cũng 
khẳng định: Từ khi có lửa và biết chinh phục được lửa, con người mới thoát khỏi đời sống động vật và trở thành chính con người (dẫn theo Trần Quốc Vượng, 2003). Lúc này, người ta đã thoát li khỏi việc ăn sống, uống sống để chuyển sang giai đoạn ăn chín, uống chín.

Tuy vậy, không phải ngay từ khi có lửa, có dụng cụ ẩm thực, có nguồn tài nguyên phong phú, con người có ngay một nền nghệ thuật ẩm thực như ngày nay. Nói đúng hơn là ẩm thực luôn gắn liền với lịch sử, với từng bước phát triển của đời sống kinh tế, văn hóa của dân tộc.

Chẳng hạn như Việt Nam, trải qua bao nhiêu thăng trầm của lịch sử với những năm tháng chiến tranh, đất nước chia cắt, nạn đói hoành hành khắp nơi thì khi nhắc đến ăn uống, người ta thường chỉ nghĩ đến việc cố gắng làm sao cho no bụng. Đồng thời, nghĩ đến ăn cũng chỉ là nghĩ đến trong cái bếp của gia đình, hôm nay có gì để "đưa vào miệng". Ăn uống là một chuyện thực tế rất bình thường diễn ra trong cuộc sống. Tuy nhiên, nếu nhìn một cách khách quan thì ăn uống không đơn giản như "chuyện cơm bữa" mà ngày nào chúng ta cũng trải qua. Trần Quốc Vượng (2003) cho rằng, ăn uống "là cả một chiến lược lương thực - thực phẩm của một quốc gia”. Ăn uống trở thành nét văn hóa vô cùng độc đáo - đó là điểm quan trọng khiến con người khác loài cầm thú.

Trải qua quá trình lịch sử phát triển hàng ngàn năm, con người ngày nay đã không còn chỉ ăn uống cho "no cái bụng" nữa, mà ăn uống đã trở thành một nghệ thuật và ngày càng cải tiến không ngừng. Ngày nay, nhiều người đã dùng từ "thưởng thức" để thay thế cho việc ăn uống, bởi lúc này "ăn uống” là một trong những điều thú vị trong cuộc sống, không ăn theo số lượng (ăn no), mà còn ăn theo cả chất lượng (ăn ngon). Thậm chí, ăn uống còn chứng tỏ được vai trò, địa vị xã hội của con người. Do vậy, khi ăn uống, con người quan tâm nhiều đến các mặt khác nhau của thức ăn đồ uống để thỏa mãn nhu cầu của người thưởng thức mà trước tiên là mùi vị. Cho đến nay, mùi vị vẫn được coi là một trong những đỉnh cao của nghệ thuật ẩm thực. Một thức ăn ngon, một chén trà ngon, một ly rượu ngon phải được cảm nhận trước tiên bằng vị giác và khứu giác, thậm chí cả bằng xúc giác (ăn bằng tay, hay bằng đũa, bằng thìa), rồi bằng cả thị giác. Do đó, thức ăn, đồ uống hiện nay cũng phải được chế biến, bày biện một cách đặc sắc hơn, cầu kì hơn, ngay cả cách thưởng thức thức ăn cũng đã trở thành một nghệ thuật. Nói đúng hơn, ăn đã không còn là một yêu cầu đơn thuần về phương diện sinh lí nữa. Nó đã chiếm vị trí trọng yếu trong quan hệ xã hội. Thông qua ăn, chúng ta có thể thấy được cả nhân sinh quan của con người. Quả là không sai khi nói rằng, ẩm thực chính là sự tiếp cận không chỉ ở góc độ vật chất mà cao hơn cả là ở văn hóa tinh thần.

Để đáp ứng nhu cầu thưởng thức thì sự sáng tạo trong ẩm thực là một trong những yếu tố vô cùng quan trọng. Nó không chỉ đơn giản như những gì từ điển đã giải thích. Nếu xét riêng về góc độ ngôn ngữ, thì ngay bản thân từ $a$ n trong tiếng Việt đã có sự đa dạng về ngữ nghĩa. Nghĩ đến ăn, người ta thường cho rằng phải nhai, phải nuốt, và do vậy, đối tượng của nó phải là những vật cứng, hay mềm, như “cơm, cháo, bánh, hoa quả...” Nhưng, những nhà có trẻ nhỏ thì lại thường xuyên nói đến chuyện "cho con ăn sữa", mặc dù sữa cho trẻ sơ sinh hoàn toàn là thể lỏng. Thậm chí, có lúc chất khí cũng được gọi là ăn, chẳng hạn “ăn thuốc lào"...

Như vậy, theo chúng tôi, ẩm thực là cả một quá trình thuơong thức thức ăn, đồ uống bằng các giác quan nhu vị giác, khíu giác, thị giác..., liên quan đến nhiều công đoạn khác nhau để làm ra một thức ăn, đồ uống ngon tù khâu chuẩn bị nguyên liệu đến khâu chế biến, bày biện, cách kết hợp thức ăn, đồ uống khác nhau, cách sư dụng vật dụng... Rồi sau đó mới là động tác đưa vào miệng, nhai, nhâm 
nhi, thưởng thức. Đó là chưa nói đến những yếu tố ngoại cảnh như những người cùng ăn, địa điểm ăn...

Cùng với sự phát triển của đời sống và văn minh xã hội, động từ ăn uống cũng dần dần phát triển thành tiểu trường hoạt động thưởng thức món ăn, đồ uống.

Hoạt động thưởng thức thức ăn, đồ uống là một hệ thống các hoạt động đa dạng và phức tạp, phản ánh các đặc trưng văn hóa dân tộc. Có thể nói rằng, ăn uống gắn liền với hoạt động của miệng. Riêng con người, ăn uống còn cần có sự góp mặt của đôi tay với cách sử dụng dụng cụ ẩm thực. Từ thời xa xưa, người nguyên thủy mới biết sử dụng những công cụ hái lượm, săn bắn, mà chưa có các dụng cụ phục vụ việc ăn uống, người ta chủ yếu dùng tay bốc thức ăn, đưa đồ uống vào miệng. Về sau, con người bắt đầu biết sử dụng các dụng cụ thô sơ để cắm hay xiên thức ăn, rồi biết khoét lỗ nhỏ trên vật thể để chứa đồ uống. Ngày nay, chúng ta đã biết cách sử dụng dụng cụ ẩm thực để thưởng thức thức ăn, đặc biệt với Trung Quốc và Việt Nam là cách dùng đũa để gắp, xiên,... thức ăn.

Từ góc độ ngôn ngữ học, hoạt động thưởng thức thức ăn, đồ uống có thể chia thành ba loại sau :

Hoạt động ăn uống nói chung gồm các động từ như: 吃 ngật (ăn), 尝 thuờng (nếm), 服phuc (uống), 喝 hát (uống), 抽 trì̀u (hút), 吸喝 hấp hát (uống hút), 喂úy (bón), 食thưc (ăn), 餐 xan (ăn), 饮ẩm (uống, văn viết), 品 phẩm (thưởng thức), 品尝 phẩm thuờng (thưởng thức), 浉 táp (tợp) (trong tiếng Hán) và lót dạ, nhâm nhi, nhấm nháp, tráng miệng, ăn, chén, đớp, măm, ngốn, tọng, xơi, hốc, bón, bú, đưt, mớm, nốc, nếm, nhắm, nhậu, uống, húp, tớp, tợp, hút (trong tiếng Việt).

Hoạt động của miệng, bao gồm các động từ như : 含hàm (ngậm), 咽 yến (nuốt), 咬 giảo (cắn), 吞 thốn (nuốt), 嚼tuớc (nhai), 啃 khẳng (gặm), 衔hàm (ngậm), 噍tiếu (nhai), 咀 thu (nhai), 嗑hạp (cắn), 喂养 úy duỡng (bón) (trong tiếng Hán) và: cắn, gặm, nhá, nhai, ngậm, mút, liếm, nuốt (trong tiếng Việt).

Hoạt động của tay, gồm các động từ như: 夹 giáp (gắp), 盛thành (xới), 捞lao (vớt), 抓 trảo (bốc), 舀yểu (múc) (trong tiếng Hán) và bốc, và, xới, đơm, xúc, gắp, bốc, nhón, chạm, nâng (trong tiếng Việt).

Có thể thấy rằng, các từ chỉ hoạt động thưởng thức thức ăn, đồ uống trong tiếng Hán và tiếng Việt có số lượng rất phong phú, đặc biệt là hiện tượng đồng nghĩa, gần nghĩa. Những động từ đồng nghĩa thường khác nhau về sắc thái hoặc phạm vi sử dụng. Chúng tôi lấy tiếng Hán làm ví dụ, chẳng hạn, cùng với nghĩa là “uống", nhưng喝 hát dùng cho cả bút ngữ và khẩu ngữ, với mọi đối tượng là chất lỏng, 饮ẩm chỉ dùng cho văn viết, 服 $p h u c$ lại có đối tượng chủ yếu là các loại thuốc và thường dùng trong văn viết, 抽 trì̀u, 吸喝 hấp hát chủ yếu dùng trong văn viết, nhưng 抽 trù̀u là uống bằng cách hút, còn吸喝 hấp hát là uống và hút nói chung. Hoặc cùng biểu thị nghĩa là “ăn", nhưng 吃 ngật (ăn) là tù được sử dụng rộng rãi trong cả khẩu ngữ và văn viết, còn食thưc và 餐 $x a n$ chỉ dùng cho văn viết, 餐 xan thường không dùng độc lập, chỉ dùng để nói đến các bữa cơm... Hay cùng với nghĩa là "ngậm", nhưng含hàm và衔hàm lại khác nhau về cách sử dụng, 含hàm khi sử dụng thường kết hợp với trợ từ động thái 着 trước...

Các từ ngữ chỉ hoạt động thưởng thức món ăn, đồ uống nêu trên không những thể hiện tất cả những gì liên quan đến cách thưởng thức thức ăn, mà nó còn liên quan nhiều đến các phương diện khác như nơi ăn, giờ ăn, những người ăn cùng, rồi đến việc bày biện, trang trí phòng ăn, thức ăn... Không phải ngẫu nhiên mà khi đãi khách, người chủ thường giới thiệu với khách các thức ăn và cách ăn, nhất là các loại nước chấm. Thông qua cách thức tổ chức bữa ăn, chúng ta có thể cảm nhận được đặc trưng văn hóa của từng dân tộc.

Nguyên liệu, cách thức chế biến, cũng như thức ăn là những tiền đề để dẫn đến hành động 
ăn, uống - khâu cuối cùng trong hoạt động ẩm thực. Và để ăn hoặc uống, người ta phải có thời gian, địa điểm và quan hệ với người cùng ăn, rồi sử dụng các dụng cụ ẩm thực và thực hiện các động tác khác nhau để có thể thưởng thức thức ăn. Rõ ràng là hoạt động thưởng thức thức ăn, đồ uống liên quan đến rất nhiều phương diện, cả mặt vật chất và mặt tinh thần.

Chúng tôi đã thống kê trong nguồn ngữ liệu (bao gồm cả thành ngũu, tục ngũu, ca dao) các cách nói biểu thị hoạt động thưởng thức thức ăn, đồ uống của người Trung Quốc và người Việt Nam. Kết quả cho thấy, trong tiếng Việt, biểu thị hoạt động thưởng thức trong ẩm thực thường có hai dạng:

(1) Có sự xuất hiện của động từ ăn/ uống/ 吃ngật /喝 hát, chẳng hạn: ăn chín uống sôi, 吃辣 ngật lạt (ăn cay), 喝大杯 hát đại bôi (uống cốc lớn)...

(2) Không có sự xuất hiện của động từ ăn/ uống/吃ngật/喝hát, chẳng hạn: một miếng giữa đàng bằng một sàng xó bếp, há miệng chờ sung, 节衣缩食 tiết y súc thưc (nhịn ăn nhịn mặc)...

Những cách nói xuất hiện động từ ẩm thực có số lượng phong phú hơn rất nhiều so với các cách nói không xuất hiện động từ ẩm thực (với tổng số 103 từ ngữ trong tiếng Việt). Hơn nữa, các cách nói sử dụng động từ ẩm thực có thể nói là nguyên dạng của các cách nói không sử dụng động từ ẩm thực. Do đó, trong bài viết này, chúng tôi lựa chọn phân tích các cấu trúc có xuất hiện động từ

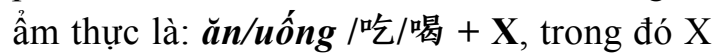
rơi vào các trường hợp sau:

(1) $X=$ danh từ biểu thị thức ăn hoặc loại thức ăn (gồm 29 từ ngữ), ví dụ: ăn ghém, ăn gỏi, ăn trầu, 吃独食 ngật độc thưcc (ăn mảnh), 喝 喜酒 hát hỉ tưu (uống rượu hỉ), 吃醋 ngật thố (ăn giấm) (ghen tuông), 吃快餐 ngật khoái xan (ăn thức ăn nhanh)...

Cấu trúc này là một cấu trúc mở với $X$ là tên gọi thức ăn, đồ uống. Vì vậy, số liệu thống kê trên là ở các ngữ cố định, còn các cụm từ tự do thì số lượng không hạn chế. Bởi vì, với động từ "ăn/吃ngật" thì hầu như tất cả các loại thức ăn là thể rắn hoặc có bã đều có thể xuất hiện trong mô hình cấu trúc này. Còn động từ uống thì $\mathrm{X}$ chỉ đối tượng là thể lỏng.

(2) $\mathrm{X}=$ tính từ biểu thị mùi vị, thuộc tính thức ăn, ví dụ: ăn xổi, ăn chay, ăn tươi nuốt sống, ăn ngon mặc đẹp, ăn mặn, ăn cay, 吃素 ngật tố (ăn chay)...

Tính từ chỉ đặc điểm thức ăn thường gặp trong các cụm từ này là: xổi, chay, tuooi, sống, ngon, cay, mặn, tanh, chín, nhạt, huoong, tạp... Các tính từ này có thể tạo thành các cặp đối nghĩa nhau, chẳng hạn: chay - mặn, sống - chín, mặn - nhạt..., thể hiện các đặc trưng khác nhau của thức ăn về trạng thái hoặc mùi vị.

(3) $X=$ động từ biểu thị phương thức ăn uống, ví dụ: ăn dè, ăn vụng, ăn vã, ăn chịu, ăn liền, ăn kiêng, ăn tục, 吃请 ngật thỉnh (được mời ăn)...

(4) $X=$ từ chỉ phương vị, địa điểm, ví dụ: ăn trên ngồi trốc, ăn trông nồi, ngồi trông huoóng, ăn hàng, ăn xó, 吃食堂 ngật thưc đường (ăn nhà ăn), 吃馆子 ngật quản tử (ăn quán)...

Điều đáng chú ý là những danh từ chỉ địa điểm đặt sau động từ ẩm thực có thể có hai trường hợp:

Một là những danh từ chung chỉ địa điểm ăn uống mang tính chất điển hình quen thuộc như: hàng, tiệm, hiệu, nhà hàng, quán...

Hai là những danh từ riêng chỉ tên địa điểm ăn, nhưng đó là những địa điểm đã có thương hiệu rất quen thuộc với nhiều người, thông thường là những thương hiệu thức ăn nhanh của nước ngoài du nhập vào, chẳng hạn: KFC, Loteria, $B B Q \ldots$

Ngoài ra, còn có trường hợp dùng từ chỉ địa điểm không phải là nơi trực tiếp cung cấp thức ăn như đường, xó, chợ... Sự kết hợp giữa động từ và tân ngữ trong trường hợp này thường là sự phê phán cách ăn uống không đường hoàng, ví dụ: ăn xó, ăn đường...

(5) $\mathrm{X}=$ danh từ chỉ vật dụng, ví dụ: ăn 
thia, ăn bát vàng, ăn đấu, ăn thúng, ăn đũa, ăn bát mẻ, 吃大碗 ngật đại oản (ăn bát lớn), 吃 筷子 ngật khoái tư (ăn bằng đũa)...

Công cụ ở đây có thể chỉ vật chứa, như bát ô tô, 大碗 đại oản (bát lớn), cũng có thể là dụng cụ thao tác, như dĩa, đũa刀叉 đao xoa (dao dĩa), 筷子 khoái tử (đũa)". Những dụng cụ đứng sau động từ ăn, 吃ngật trong trường hợp này thường là những dụng cụ có đôi có cặp, chúng có sự chế ước, bổ sung lẫn nhau, chẳng hạn đũa - dao dĩa, cốc lớn - cốc bé, bát lớn-bát bé... Khi nói ăn bằng dao dĩa, 吃 刀叉 ngật đao xoa, người nghe sẽ liên tưởng đến ăn bằng đũa, 吃筷子ngật khoái tủ. Do đó, những từ chỉ công cụ không thành cặp thì không thể làm bổ ngữ chỉ công cụ cho động từ loại ăn, 吃 ngật (ăn), uống, 喝 hát (uống).

(6) $\mathrm{X}=$ danh từ chỉ sự việc hoặc thời điểm ăn (3 đơn vị), như: ăn cố, ăn tiệc, 吃喜糖 $n g \hat{a} t$ hi đường (ăn kẹo cưới) ...

(7) $\mathrm{X}=$ động từ tiến hành đồng thời (gồm 2 đơn vị), như: ăn nhậu, 吃喝ngật hát (ăn uống)...

(8) $\mathrm{X}=$ tính từ/động từ biểu thị kết quả (gồm 3 đơn vị), như: ăn no, ăn hai , 吃闲饭 ngật nhàn phạn

(9) $\mathrm{X}=$ động từ biểu thị mục đích (gồm 1 đơn vị), như: ăn mùng, 吃喜酒 ngật hỉ tửu...

(10) $X=$ đối tượng cùng ăn (gồm 1 đơn vị): ăn cùng bạn, 与朋友吃 dĩu bằng hưu ngật...

Các kết cấu trên phần nào đã phản ánh đặc điểm cách ăn của người Trung Quốc và người Việt Nam về các phương diện khác nhau như phương thức ăn (ăn ghém, ăn xổi, ăn gỏi), tục lệ (ăn trầu, ăn chay), cách ứng xử khi ăn (ăn tục, ăn vung), đời sống kinh tế xã hội (ăn dè, ăn chịu, ăn hàng, 吃宾馆 ngật tân quán (ăn khách sạn),...).

\section{4. Ăn uống trong mối liên hệ với các hành vi đối nhân xử thế của con người}

Thông qua các hoạt động ăn uống, người Việt Nam đã liên tưởng đến các hoạt động khác của con người. Điều này thể hiện một cách sinh động qua hàng loạt các câu thành ngữ. Chúng tôi đã khảo sát 199 thành ngữ, tục ngữ có yếu tố ăn trong tiếng Việt, kết quả cho thấy, động từ ăn thường được sử dụng với các động từ khác thành từng cặp. Trong đó, các động từ đi cùng với ăn có tần số xuất hiện nhiều nhất là: các động từ liên quan đến nói năng (nói, bạch, kháo) với tổng số 31/199 câu, ví dụ: ăn bớt bát, nói bớt lời...; các động từ liên quan đến việc báo đáp ân tình (trả, nhớ...), với tổng số 30/199 câu, ví dụ : ăn mận trả đào...; các động từ liên quan đến hoạt động sinh hoạt hàng ngày khác (như ở, nằm, làm, ngủ, ngồi, mặc), ví dụ: ăn thật làm dối, ăn tại phủ, ngủ tại công đường, ăn không ngồi rồi, ăn ngon mạc đẹp... Điều này chứng tỏ, ăn có mối liên hệ mật thiết với các hành vi ứng xử khác của con người. Trong đó, chủ yếu là cách nói năng, cách báo đáp công ơn và các hành vi thường gặp khác trong cuộc sống thường nhật như nằm, làm, ngủ, ngồi, mặc. Dưới đây, chúng tôi phân tích ăn uống trên hai phương diện cụ thể là $\breve{A n}$ uống với việc báo đáp công ơn và $\breve{A n}$ uống với cách nói năng và cur xủ khác.

\section{1. Ăn uống với việc báo đáp công ơn}

Uống nước nhớ nguồn là truyền thống tốt đẹp của dân tộc Việt Nam. Người Việt Nam quan niệm, báo đáp người khác cũng là một phần nghệ thuật sống. Bởi nó đòi hỏi sự tinh tế, khéo léo, thể hiện được tấm lòng biết ơn chân thành. Trước hết, khi được hưởng lợi từ người khác, người Việt luôn có cách tri ân bằng việc "khắc cốt ghi tâm", không quên ơn là một trong những phẩm chất đạo đức của người Việt. Những cách răn dạy chí lí chí tình này đã thể hiện ngay trong các câu thành ngữ, tục ngữ có sử dụng cặp động từ ăn và $n h o ̛$, ví dụ: ăn quả nhớ kẻ trồng cây, ăn gạo nhớ kẻ đâm xay tối ngày... Tri ân luôn là nỗi canh cánh trong lòng người Việt, họ muốn tìm cách để đền đáp công ơn bằng hành động hoặc vật chất có giá trị tương đồng thậm chí cao hơn so với những gì nhận được. Điều này được bộc lộ ngay trong những câu nói có sử dụng cặp động từ ăn và trả, chẳng hạn: ăn mận trả 
đào, ăn đấu trả bồ, ăn tám lạng, trả nưa cân, ăn miếng chả, trả miếng bùi,... có sự tương xứng giữa mận - đào, đấu - bồ, tám lạng nưa cân, miếng chả - miếng bùi...; ăn cám trả vàng lại thể hiện cách trả ơn hậu hĩnh. Với người Trung Quốc, câu 饮水思源ẩm thủy tu nguyên cũng vô cùng quen thuộc. Trong bài "Mộc qua" (Kinh thi) đã có câu Đầu ngã dĩ mộc qua, báo chi dĩ quỳnh dao (Ai trao ta quả mộc đào, thì ta đem ngọc quỳnh dao tặng người), tất cả đều thể hiện truyền thống ứng xử của người Trung Quốc.

Ngược lại với cách cư xử ở trên là những thói ăn ở không có hậu gặp phải sự công kích từ dư luận, như: ăn thúng trả đấu, ăn cây táo, rào cây sung, ăn một nơi, ấp một nơi, 吃曹 操的饭, 干刘备的事一吃里爬外ngật Tào Tháo đích phạn, cán Luu Bị đích thị - ngật li ba ngoại (ăn cơm Tào Tháo, làm việc Lưu $\mathrm{Bị} \mathrm{-} \mathrm{ăn} \mathrm{cây} \mathrm{táo,} \mathrm{rào} \mathrm{cây} \mathrm{sung),} \mathrm{ăn} \mathrm{cháo} \mathrm{đá} \mathrm{bát,}$ ăn mật trả gùng... Tất cả những cách cư xử này đều bị xã hội lên án gay gắt.

Trong cuộc đời, người có công ơn nhiều nhất không ai khác là cha mẹ. Chính vì vậy, một người con hiếu thảo là người biết cách báo đáp công ơn cha mẹ, trước tiên là ở sự kính trọng và yêu quý dành cho cha mẹ, thể hiện ngay từ cách nói năng, cư xử, đối đãi với cha mẹ, trong đó có những biểu hiện trong bữa cơm hàng ngày. Con cái thường dành những món ngon cho ông bà, cha mẹ, và ngược lại ông bà, cha mẹ lại nhường cho con cháu. Đó là một nét đẹp thể hiện tình cảm gắn bó của người Việt. Thậm chí, khi đói kém, người con sẵn sàng ăn uống kham khổ để dành món ngon cho mẹ: Đói lòng ăn đọt chà là/ Để com nuôi mẹ, mẹ già yếu răng.

Cha mẹ thật hạnh phúc khi đến tuổi già vẫn nhận được sự quan tâm của con cái, dù đó là niềm hạnh phúc đơn sơ nhỏ bé như những lần con cái chuẩn bị bát cơm, bát canh hàng ngày cho mình. Chính vì lẽ đó, họ luôn mong muốn con cái được sống gần gũi với mình, dù những đứa con đó đã thành gia thất: Có con $m a ̀$ gả chồng gần / Có bát canh cần nó cũng đem cho.
Một bát canh cần tuy không phải là cao lương mĩ vị, nhưng nó lại là tình cảm thân thiết, gắn bó giữa cha mẹ và con cái, cha mẹ chỉ mong muốn sau khi con gái lấy chồng, vẫn thường xuyên được ăn những món đồng quê bình dị do chính tay con nấu, hay nói đúng hơn là được gần gũi con cái, được cảm nhận sự quan tâm của con cái với mình. Bát canh cần đã mang theo ý nghĩa biểu trưng của lòng hiếu thảo và hạnh phúc của người già bên con cháu. Ngược lại với lòng hiếu thảo, có những kẻ bạc đãi cha mẹ, vong ân bội nghĩa. Cha ông ta đã có những câu ca dao, tục ngữ phê phán thái độ này một cách thẳng thắn: Sống thì con chẳng cho ăn / Chết thì xôi thịt làm văn tế ruồi.

Nhìn chung, một trong những biểu hiện quan trọng của tình cảm con người là quan tâm, chăm sóc lẫn nhau trong các bữa ăn hàng ngày. Lối nói "vì tình vì nghĩa, ai vì đĩa xôi đầy" đã thể hiện giá trị tinh thần cao cả trong thuộc tính xã hội của thức ăn, đồ uống cũng như tâm lý ăn uống của người Việt Nam.

\section{2. Ăn uống với cách nói năng và cu xủ khác}

Không phải ngẫu nhiên mà tiếng Việt dùng từ "ăn nói” để chỉ cách nói năng. Bởi trong quan điểm của người Việt, ăn có liên hệ mật thiết với nói về rất nhiều mặt, nhu số lượng, địa điểm, đối tượng cùng ăn, dụng cụ, thức ăn, thời điểm, động tác, đặc biệt là do cùng một bộ phận cơ thể thực hiện. Thông thường, cách ăn như thế nào thì cách nói cũng như vậy. Đó là lí do trong tiếng Việt có hàng loạt các câu nói như: ăn bớt bát, nói bớt lời, ăn lắm, nói nhiều, ăn cơm nhà no, kháo cà nhà kia, ăn cùng chó, nói xó cùng ma, ăn nên đọi, nói lên lời, ăn ốc, nói mò... Người thanh lịch là người ăn uống từ tốn, nhỏ nhẹ, ăn đúng chỗ đúng lúc, biết chọn thức ăn, người cùng ăn cho phù hợp... Đồng thời, đó cũng là người biết suy nghĩ kĩ trước khi nói, từ tốn, nhẹ nhàng, đúng lúc, đúng người, đúng việc... Rõ ràng là, ăn và nói thể hiện trình độ văn hóa của mỗi người. 
Ngoài ra, người Việt còn thông qua cách thưởng thức thức ăn, đồ uống để phê phán cách ứng xử khác của con người.

Trước hết là sự phê phán những hành động, cử chỉ thiếu lịch sự, biểu hiện của kẻ "phàm phu tục tưo", trong đó không thể không nhắc đến kết cấu $\breve{\boldsymbol{a}} \boldsymbol{n} \boldsymbol{n h u} \boldsymbol{X}$, chẳng hạn: $\breve{A n} n h u$ hủi ăn thịt mõ, $\breve{A n}$ nhu hùm đổ đố, $\breve{A n}$ nhu mỏ khoét, Ăn nhu phát tấu... Các yếu tố $\mathrm{X}$ gợi hình ảnh về một người hoặc vật có sức khỏe hoặc đang tiến hành một hoạt động sở trường với số lượng lớn, ví dụ: thuồng luồng, thơ đấu, Thạch Sanh, gấu ăn trăng, Nam Hạ vác đất, hủi ăn thịt mõo... Cũng nói về cách ăn uống tham lam, người Việt Nam còn sử dụng kết quả của sự ăn để phê phán, chẳng hạn: 夰 mòn bát mòn đũa, $\breve{A n}$ sút đũa mẻ bát, $\breve{A n}$ thủng nồi trôi chõ... Đó là những cách so sánh ví von hết sức hài hước, nhưng cũng không kém phần sâu sắc của người Việt Nam về cách ứng xử trong ăn uống.

Đối với người Trung Quốc, số lượng thức ăn sử dụng được liên tưởng với phong cách xử lí công việc. Trong đó, số lượng thường gặp là 一口 nhất khẩu (một miếng). 一口 nhất khẩu (một miếng) chỉ một lần đưa thức ăn vào miệng để ăn. Với mỗi một lần ăn, người ta chỉ có thể ăn được lượng thức ăn vừa đủ cho khoang miệng vận hành, và kết quả đạt được không thể tương đương với việc ăn nhiều, ăn hàng tháng, hàng năm được. Chính vì vậy, chỉ với một lần đưa thức ăn vào miệng mà ăn với số lượng thức ăn lớn hơn bình thường như: 口吃了十二个饺子nhất khẩu ngật liễu thạp nhị cá giảo tủ (ăn một hơi/ miếng hết 12 cái sủi cảo), 一口想吃九个馒头nhất khẩu tuoởng ngật cửu cá màn thầu (một hơi ăn/ miếng hết 9 cái màn thầu)... đều là sự mô tả hành động của kẻ tham lam. Nếu chỉ với một lần đưa thức ăn vào miệng mà muốn có tác động ngay đến cơ thể thì đó là cách nói phê phán sự nóng vội, như : 一口想吃个胖子nhất khẩu ngật cá phán tủ (ăn một miếng thành người béo: dục tốc bất đạt). Nếu là những thức ăn cần phải ăn từ từ thì đó là cách nói phê phán hành động vội vàng không hấp thu được, chẳng hạn: 一 口吃个牛排nhất khẩu ngật cá nguu bài (một miếng ăn hết cả cái sườn bò), dùng để ví với sự tham lam, ăn nhiều, nhai không nổi)...

Từ những phân tích ở trên, có thể thấy bất kì một thức ăn nào cũng có những cách ăn nhất định, đó là căn cứ để chọn ăn phần nào, không ăn phần nào, ăn với tốc độ ra sao, thời điểm nào, chẳng hạn: ăn cá bỏ vây, ăn đường nuốt chậm, ăn cóc bỏ gan, ăn trầu nhả bã... Những cách ăn này rất quen thuộc trong đời sống sinh hoạt, nhưng đã được liên tưởng đến cách sống của con người: không nên quá tham lam để dẫn đến hậu quả khôn lường. Những cách cư xử không tương xứng giữa ăn và làm luôn nhận được sự phê phán ý nhị của người Việt: Ăn hàng con gái, đái hàng bà lão; Kẻ ăn ốc, người đổ vỏ...

Thời điểm cũng là yếu tố vô cùng quan trọng khi thưởng thức món ăn. Ăn món nào vào thời điểm nào đã được liên tưởng đến cách thức xử lí công việc. Các loại thức ăn nếu sử dụng đúng vào thời điểm đã nêu ở trước thì biểu thị việc làm hợp lí, đúng thời điểm, có tác dụng, còn nếu không đúng theo quy luật logic vào thời điểm đó thì biểu thị việc làm vô ích, không đúng, mang lại cảm giác khó chịu. Chẳng hạn口渴喝盐汤——徒 劳无益khẩu khát hát diêm thang - đồ lao vô ich (khát uống canh mặn - nhọc công vô ích), 八月十五吃月饼一正是时候bát nguyệt thập ngũ ngật nguyệt bính - chính thị thời hậu (15/8 ăn bánh trung thu - đúng lúc), 半 夜吃黄瓜一不知头尾 bán da ngật hoàng qua - bất tri đầu vĩ (nửa đêm ăn dưa chuột không biết đầu đuôi)... Thời điểm ăn có thể là một ngày cụ thể như 五月天ngũ nguyệt thiên (ngày tháng 5), 八月十五bát nguyệt thập $n g \tilde{u}(15 / 8)$, 端午节đoan ngo tiết (tết đoan ngọ)..., một thời điểm trong ngày như 半夜 bán dạ (nửa đêm), hoặc một mùa trong năm như 冬天 đông thiên (mùa đông), 夏天 $h a$ thiên (mùa hạ)..., hoặc khi xảy ra một việc gì, chẳng hạn 泻肚子 tả đỗ tủ (bị đi ngoài), 口渴khẩu khát (khát nước)... 
Sự tham lam thường đi đôi với sự lười biếng, chỉ biết ăn mà không biết làm, như: $\breve{a n}$ không ngồi rồi, ăn no rồi lại nằm quèo, ăn thì cúi trốc, đẩy nóc thi van làng, 吃现成饭 ngật hiện thành phạn (ăn sẵn), 吃闲饭ngật nhàn phạn (chỉ ăn mà không làm), 又想吃鱼又怕 腥 hưu tuởng ngật ngu hưu phạ tinh (vừa muốn ăn cá vừa sợ tanh: vừa trèo vừa run).... Trong quan niệm của người Trung Quốc và người Việt Nam, có làm thì mới có ăn, những người ỷ lại, dựa dẫm sớm muộn sẽ bị đào thải.

Nói chung, "ăn trông nồi, ngồi trông hướng" là truyền thống ứng xử trong ăn uống của cả người Trung Quốc và người Việt Nam. Sự từ tốn, ý nhị, quan tâm, chia sẻ lẫn nhau khi ăn uống là nét đẹp văn hóa của cả hai dân tộc.

\section{Kết luận}

Từ ngữ ẩm thực trong đó có nhóm động từ thưởng thức món ăn, đồ uống là lớp từ rất đa dạng, phong phú cả về số lượng và ý nghĩa. Nó phản ánh một mặt không thể thiếu trong đời sống con người - vấn đề ăn uống. Ở Việt Nam cũng như ở Trung Quốc, việc nghiên cứu về văn hóa ẩm thực đã và đang đạt được nhiều thành quả đáng ghi nhận. Cách tiếp cận vấn đề từ góc độ ngôn ngữ học luôn mang lại những cách nhìn nhận khách quan về một vấn đề ẩn chứa những đặc trưng văn hóa dân tộc vô cùng sâu sắc.

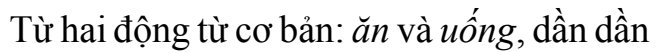
phát triển ngày càng đa dạng, hình thành nên nhóm động từ chỉ hoạt động thưởng thức món ăn, đồ uống vừa có thể độc lập thành từ, vừa có khả năng kết hợp linh hoạt với các khách thể biểu thị đối tượng ăn, uống khác nhau. Đặc biệt là trong tiếng Việt, ngoài những động từ chỉ hoạt động thưởng thức món ăn, đồ uống là từ thuần Việt ra, còn có một số lượng nhất định từ mượn tiếng Hán, mỗi loại có sắc thái biểu cảm khác nhau. Động từ chỉ ăn uống còn mở rộng phạm vi kết hợp và mở rộng nghĩa, tạo nên các ngữ cố định và không cố định với những tầng nghĩa ví von, so sánh khác nhau, thể hiện mối liên hệ giữa ẩm thực với nhiều mặt của đời sống xã hội, trong đó có khía cạnh đạo đức xã hội, khiến cho nhóm động từ này có thể vượt lên giới hạn ngôn ngữ, vươn tới lĩnh vực văn hóa dân tộc.

Nhóm động từ chỉ ăn uống trong tiếng Hán và tiếng Việt có nhiều điểm tương đồng, song cũng có những điểm khác biệt nhất định. Chúng đều là chứng cứ ngôn ngữ phản ánh quá trình phát triển của đời sống vật chất và tinh thần. Đồng thời thể hiện rõ nét khả năng tư duy liên tưởng của hai dân tộc, góp phần làm phong phú cho lớp từ ẩm thực nói chung trong tiếng Hán và tiếng Việt.

\section{Tài liệu tham khảo}

\section{Tiếng Việt}

Đào Duy Anh (2010). Việt Nam văn hóa sủ cuong. Hà Nội: NXB Văn học.

Đỗ Hữu Châu (1997). Tù vụng ngũ nghĩa tiếng Việt. Hà Nội: NXB Đại học Quốc gia Hà Nội.

Trần Văn Cơ (2006). Ngôn ngũ học tri nhận (ghi chép và suy nghĩ). Hà Nội: NXB Khoa học xã hội.

Xuân Huy (sưu tầm và giới thiệu) (2000). Văn hóa ẩm thực và thức ăn Việt Nam. Hà Nội: NXB Trẻ.

Hoàng Phê (2011). Tù điển tiếng Việt. Đà Nã̃ng: NXB Đà Nẵng, Trung tâm từ điển học.

Lê Quang Thiêm (2008). Ngũ nghĩa học. Hà Nội: NXB Giáo dục.

Trần Quốc Vượng (2003). Văn hóa Việt Nam tìm tòi và suy ngẫm. Hà Nội: NXB Văn học.

\section{Tiếng Trung}

常敬宇 (2009) 。《汉语词汇文化》，北京大学出版 社

董为光 (1995). 《汉语 '吃 , 类说法文化探源》, 语言研究第2 期

郭锦桴 (1993)。 《汉语与中国传统文化》，中国人 民大学出版社

刘冬慧 (2008). 《中国古代汉语中的饮食类动词及 有关文化研究》，昆明冶金高等科学校学报第 24 卷第 2 期

陆庆和 (1995)。《说 “食’ 类用语》，语言文字应 用, 第二期

王国安、王小曼 (2003)。《汉语词语的文化透视》, 汉语大词典出版社

杨菊华 (1994). 《中华饮食文化》, 首都师范大学 出版社

赵守辉 (1991). 《汉语与饮食文化》, 汉语学习第5 期

中国烹杄协会美食营养专业委员会，《精选家常主 食1088例》，新世界出版社 


\title{
EATING-RELATED VERBS IN CHINESE AND VIETNAMESE
}

\author{
Ngo Minh Nguyet \\ Faculty of Chinese Language and Culture, VNU University of Languages and International Studies, \\ Pham Van Dong, Cau Giay, Hanoi, Vietnam
}

\begin{abstract}
Cuisine is one of the most important issues in the language and culture of many countries, including China and Vietnam. It is often said that eating is the most basic human activity. As society develops, eating habits have reached the level of art which can be clearly shown in language. Therefore, the formation of eating-related verbs in Chinese and Vietnamese is increasingly diversified. Through human imagination, the meaning layers of those verbs are becoming varied which enriches the vocabularies of the two languages. In the article, by means of research techniques such as statistics, description, analysis, an attempt is made to clarify the features of language and culture as well as the relationship between eating-related verbs in Chinese and those in Vietnamese.

Keywords: verbs, eating, Chinese, Vietnamese
\end{abstract}

